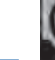

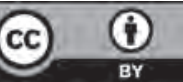

MARCIN KUPIŃSKI

Henkel Polska

e-mail: marcin.kupinski@henkel.com

KAROLINA STOBIENIECKA

Henkel Polska

KAROL SKOWERA

Politechnika Świętokrzyska

e-mail:kskowera@tu.kielce.pl
Manuscript submitted 2019.12.03 - revised 2020.01.10, initially accepted for publication 2020.02.19, published in March 2020

\section{INFLUENCE OF LIGHTWEIGHT FILLERS ON THE PERFORMANCE OF CEMENT-BASED SKIM COAT}

\section{WPLYW LEKKICH WYPEENIACZY NA PARAMETRY UŻYTKOWE GKADZI CEMENTOWE}

DOI: $10.30540 / \mathrm{sae}-2020-001$

\begin{abstract}
A b stract
Lightweight fillers are used in dry-mixed building mortars in order to improve thermal insulation properties, yield, and workability. In the case of thin layer products, used as a finishing layer, reduced thermal conductivity coefficient enables to restrain of water vapor condensation on walls - which inhibits mold growth. The aim of the study was to determine the influence of 4 types of lightweight fillers on the performance of cement-based skim coat-with emphasis on the economic aspect. Formulas reflecting typical commercial products were used. The dosage of different components -such as expanded perlite, glass and polymeric bubbles or expanded glass - was optimized for sufficient yield and workability, keeping the constant price of $1 \mathrm{~kg}$ of the final product. Mechanical parameters, capillary absorption coefficient, and thermal conductivity coefficient were determined. Observations by Scanning Electron Microscope revealed poor incorporation of polymer microspheres in the cement matrix, leading to loss of mechanical strength. With the addition of expanded glass, an increase of flexural and compressive strength thanks to the pozzolanic reaction was observed. Glass bubbles were found the most effective additive.
\end{abstract}

Keywords: lightweight fillers, perlite, microspheres, expanded glass

\section{Streszczenie}

Stosowanie lekkich wypetniaczy w suchym mieszankach chemii budowlanej pozwala na poprawę termoizolacyjności, wydajności oraz właściwości roboczych zapraw. W przypadku cienkowarstwowych wyrobów wykończeniowych obniżony wspótczynnik przewodzenia ciepła hamuje kondensację pary wodnej na ścianach wewnętrznych, redukując powstawanie pleśni. Celem przeprowadzonych badań byto określenie wptywu czterech rodzajów lekkich wypetniaczy na właściwości gładzi cementowej, ze szczególnym uwzględnieniem aspektu ekonomicznego. Sporządzono receptury odzwierciedlajace skład typowych komercyjnych produktów. Dozowanie poszczególnych dodatków: perlitu ekspandowanego, kulek szklanych i polimerowych oraz spienionego szkła, zoptymalizowano pod katem odpowiedniej wydajności oraz konsystencji, zachowując przy tym stała cenę $1 \mathrm{~kg}$ ostatecznego wyrobu. Dokonano pomiarów właściwości mechanicznych, absorpcji kapilarnej oraz wspótczynnika przewodzenia ciepła. Obserwacje pod skaningowym mikroskopem elektronowym pozwolity wykazać niska przyczepność mikrosfer polimerowych do matrycy cementowej prowadzaca do pogorszenia wytrzymatości. Przy dodatku granulowanego spienionego szkła zaobserwowano wzrost wytrzymałości na zginanie i ściskanie na skutek reakcji pucolanowej. Za najkorzystniejszy uznano dodatek kulek szklanych.

Słowa kluczowe: lekkie wypełniacze, perlit, mikrosfery, ekspandowane szkło 


\section{INTRODUCTION}

The too high humidity of interiors caused by nonefficient ventilation has become an important topic, especially for multi-family housing. Excess of water vapor tends to condense on walls, creating conditions for the growth of fungi, negatively influencing humans' health [1].

Such an effect can be reduced by using of anticondensation layers - the most popular are paints and coatings. Their action can be based on two different mechanisms: absorption and storage of water vapor and increased thermal insulation properties, where the last one generally plays a bigger role [2].

The addition of lightweight fillers to the material allows for the reduction of the thermal conductivity coefficient [2-4]. Wang et al. [4] confirm also the possibility to improve anti-condensation properties, by showing the correlation between the increase of expanded perlite content and reduction of water vapor condensation for coatings of layer thickness between $1 \mathrm{~mm}$ to $2.5 \mathrm{~mm}$. Moreover, the usage of lightweight fillers in mortars introduces a wide range of benefits. Namely: the higher yield (understood as increased covering capacity calculated per square meter) and reduced bulk density. This property enables producers to increase the price for $1 \mathrm{~kg}$ of finished product keeping the constant price for one bag - thanks to reduced mass in the packaging. Addition of lightweight fillers often improves application properties of product - such as easiness of application by the craftsmen, coming from reduced density, viscosity and higher aeration [5].

Such as higher yield and improved workability. Lowered bulk density allows for weight reduction in the bag of the final product.

Typically used lightweight fillers can be natural (expanded: perlite, vermiculite), synthetic (polymer or glass microspheres) or waste origin (expanded glass powder or aluminosilicate cenospheres obtained as the lightest fraction of ashes from coal burning). Their mutual feature is low density - below 1200 $\mathrm{kg} / \mathrm{m}^{3}$ [6] - as a result of high internal porosity. However, they can vary in shape, microstructure, and pozzolanic activity [7].

One very common and widely disputed in the literature $[8,9]$ lightweight fillers is perlite - volcanic rock which, after excavation, was milled and made to expand - at the high-temperature process of swallowing caused by an expansion of water entrapped inside the rock. The obtained material is basically low-density aluminosilicate glass containing small amounts of sodium, potassium, iron, calcium, and magnesium. It is characterized by open pore system. Lanzon et al. [5] proves this could lead to significant increase of water absorptivity of mortars. Absorption of water after $30 \mathrm{~min}$ of cement-based render with $1.18 \%$ and $3.54 \%$ addition of perlite was increased from $3.01 \%$ mass to, respectively, $6.11 \%$ and $23.65 \%$ mass.

Such disadvantage is not the case for synthetic microspheres - glass or polymer based [10]. Polymer microspheres are made in water suspension. The organic phase is a mixture of monomers with a blowing agent. Thanks to the addition of surfactants and stabilizers, the suspension is kept in the form of droplets. Heating up the system initiates the polymerization process inside the droplet with simultaneous expansion of gas coming from the decomposition of the blowing agent. As the polymer formed is insoluble in any of the present phases it precipitates at the border between the organic phase and water, creating the shell of the microsphere [11].

Glass microspheres are most typically produced in a constant process of feeding pre-treated portions of the mixture of glass powder and blowing agent to the flame of a gas burner. In the flame, by the action of high temperature $\left(>1000^{\circ} \mathrm{C}\right.$ depending on glass used), the blowing agent decomposes with the creation of expanding gas. At the same time, glass starts to melt and spheroidize spontaneously because of surface tension. After leaving the flame rapid cooling occurs and the hard shell of hollow grain is formed [12].

In both cases, product obtained is characterized by favourable spherical shape with smooth shells and closed porosity [11, 12]. Brooks et al. [13] provides comprehensive comparison of light cement-based mortars with density in the range of $1300-2084 \mathrm{~kg} / \mathrm{m}^{3}$ and $\mathrm{W} / \mathrm{C}=0.43$ with addition of polymer and ceramic microspheres in various dosages. As the authors indicate, the addition of polymer microspheres in the amount of $28.5 \%$ by volume, allowed for decreasing thermal conductivity coefficient from $2.23 \mathrm{~W} /(\mathrm{m} \cdot \mathrm{K})$ to $0.69 \mathrm{~W} /(\mathrm{m} \cdot \mathrm{K})$ - but the compressive strength was decreased from 49.71 MPa to 12.68 MPa. The addition of the same amount of glass microspheres allowed for achieving similar thermal conductivity coefficient $(0.70 \mathrm{~W} /(\mathrm{m} \cdot \mathrm{K}))$, with conserving the mechanical strength of $48.50 \mathrm{MPa}$. The authors notice the importance of quality of incorporation of fillers into the cement matrix.

Type of porosity (open or closed) as well as chemical reactivity (or lack thereof) of lightweight 
fillers relative to the cement matrix, shapes the final properties of the material to a great extent [7]. In the presented study, the influence different lightweight fillers on mechanical parameters, thermal conductivity and water absorptivity of cement-based skim coat, was compared.

\section{MATERIALS AND METHODS}

4 different types of lightweight fillers of different origin and production processes were examined. Expanded perlite with grains covered by a hydrophobic agent in order to reduce water absorption was used, as well as glass and polymer microspheres, and granulated expanded glass - waste material obtained by recycling of consumer glass (mainly soda-lime). Milled bottles powder was expanded in a similar way as perlite, resulting in low density.

All the lightweight fillers used are commercially available as raw materials to formulate construction mortars. Details of production process are the secrets of manufacturers. Physicochemical characteristics of materials is presented in Table 2. Information regarding composition are based on material datasheets. Grain size distribution of fillers was tested by laser diffractometry with Helos KR apparatus.
Measurements were made in the air stream. A comparison of grain size distribution is presented in Figure 1. Bulk density of fillers, as well as of dry mixes obtained was measured according to EN 10973:2000.

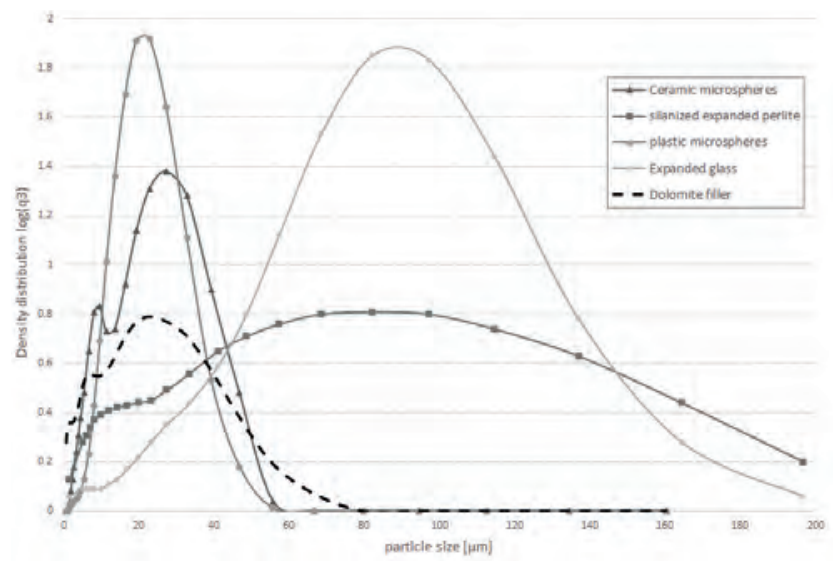

Fig. 1. Grain size distribution of light fillers used

The matrix was the skim coat made of white portland cement CEM I 52.5 R with the addition of hydrated lime and redispersible polymer powder (based on vinyl acetate). Fillers were limestone and dolomite flours with grain sizes between 0-100 $\mu \mathrm{m}$.

Table 1. Formulas

\begin{tabular}{|l|c|c|c|c|c|}
\hline \multicolumn{1}{|c|}{ Composition [\%] } & Z1 & Z2 & Z3 & Z4 & Z5 \\
\hline White CEM I52.5R & 20.0 & 20.0 & 20.0 & 20.0 & 20.0 \\
\hline Dolomite & 38.0 & 35.0 & 33.0 & 37.5 & 35.0 \\
\hline Calcium Carbonate & 39.0 & 39.0 & 39.0 & 39.0 & 39.0 \\
\hline Hydrated Lime & 1.0 & 1.0 & 1.0 & 1.0 & 1.0 \\
\hline Organic compounds & 2.0 & 2.0 & 2.0 & 2.0 & 2.0 \\
\hline Silanized expanded perlite & & 3.0 & & & \\
\hline Expanded glass & & & 5.0 & & \\
\hline Glass microspheres & & & & & \\
\hline Plastic microspheres & & & & & \\
\hline Water demand [\%] & 39.0 & 40.0 & 38.0 & 40.0 & 43.0 \\
\hline W/C ratio [-] & 1.95 & 2.00 & 1.90 & 2.00 & 2.15 \\
\hline Bulk density [g/dm ${ }^{3}$ ] & 0.89 & 0.79 & 0.83 & 0.80 & 0.69 \\
\hline
\end{tabular}

Table 2. Properties of lightweight fillers used

\begin{tabular}{|l|l|c|c|c|c|}
\hline \multirow{2}{*}{ Lightfiller } & \multicolumn{1}{|c|}{ Material } & \multicolumn{3}{c|}{ Particle size $[\mu \mathrm{m}]$} & \multirow{2}{*}{ Density $\left[\mathrm{kg} / \mathrm{m}^{3}\right]$} \\
\cline { 3 - 5 } & & $\mathbf{D}_{10}$ & $\mathbf{D}_{50}$ & $\mathbf{D}_{90}$ & \\
\hline Silanized expanded perlite & Aluminium-silicate (Silicon coated) & 12.07 & 52.13 & 117.12 & 150 \\
\hline Expanded glass & Soda-lime consumer glass & 5.59 & 68.18 & 119.02 & 600 \\
\hline Glass microspheres & Soda-lime borosilicate glass & 4.81 & 17.31 & 33.53 & 220 \\
\hline Plastic microspheres & Thermoplastic copolymer & 9.08 & 18.96 & 34.83 & 25 \\
\hline
\end{tabular}


Lightweight fillers were always added at the expense of dolomite flour - by mass. Amounts of additives were adjusted considering the economic aspect. Always a constant price of $1 \mathrm{~kg}$ of final product was kept.

In order to optimize workability parameters, a combination of rheology modifiers based on cellulose and starch ethers were used in constant dosage. Possible differences in the water demand of mortars, caused by addition of lightweight fillers, were not corrected with admixtures. It was assumed it would be too much interference in workability (plasticity, easiness of application); moreover, even small addition of cellulose or starch ether would have far more influence on hydration of cement than small change in $\mathrm{W} / \mathrm{C}$ ratio [7]. The water amount was adjusted to normative consistency according to PN-EN 1015-3:2003 "Methods of test for mortar for masonry" so that the flow of $16.5 \mathrm{~cm}$ was achieved at the flow table. Detailed formulas of mortars are presented in Table 1.

Compressive and flexural strength were determined at $4 \times 4 \times 16 \mathrm{~cm}$ prisms according to the norm: PN-EN 1015-11:2001 with a hydraulic press. Remains from the internal part of prisms after strength tests (after 28 days of hydration) were covered with gold and observed by Scanning Electron Microscope SEM FER QUANTA 250 FEG with EDS EDAX microprobe.

Capillary absorption was determined according to PN-EN 1015-18:2003 "Mortar for masonry determination of water absorption coefficient due to capillary action of hardened mortar". Additionally, according to the same norm, water absorption was measured after 15, 30, 120, $240 \mathrm{~min}$ - as the mass gain in grams, caused by capillary absorption. The samples were prepared the same way as for strength tests. The thermal conductivity coefficient was determined by a stationary method with the Bock apparatus: Stiro Lab LM.305 EPS.

\section{RESULTS AND DISCUSSION}

\subsection{Silanized Perlite}

Silanized expanded perlite shows the widest grain size distribution besides all tested fillers (Fig. 1). The volume share of an individual fraction is homogenous in all particle size range $(0-200 \mu \mathrm{m})$. Single grains show significant open porosity which can be observed by Scanning Electron Microscope (Fig. 2). Despite this fact, the addition of $3 \%$ of expanded perlite to mortar Z2 did not result in significant water demand increase comparing to the control (Z1) (Table 1).
This is thanks to effective silanization, which decreased water absorptivity of perlite and allowed for limiting the negative impact of open porosity on the consistency and workability of the skim coat.
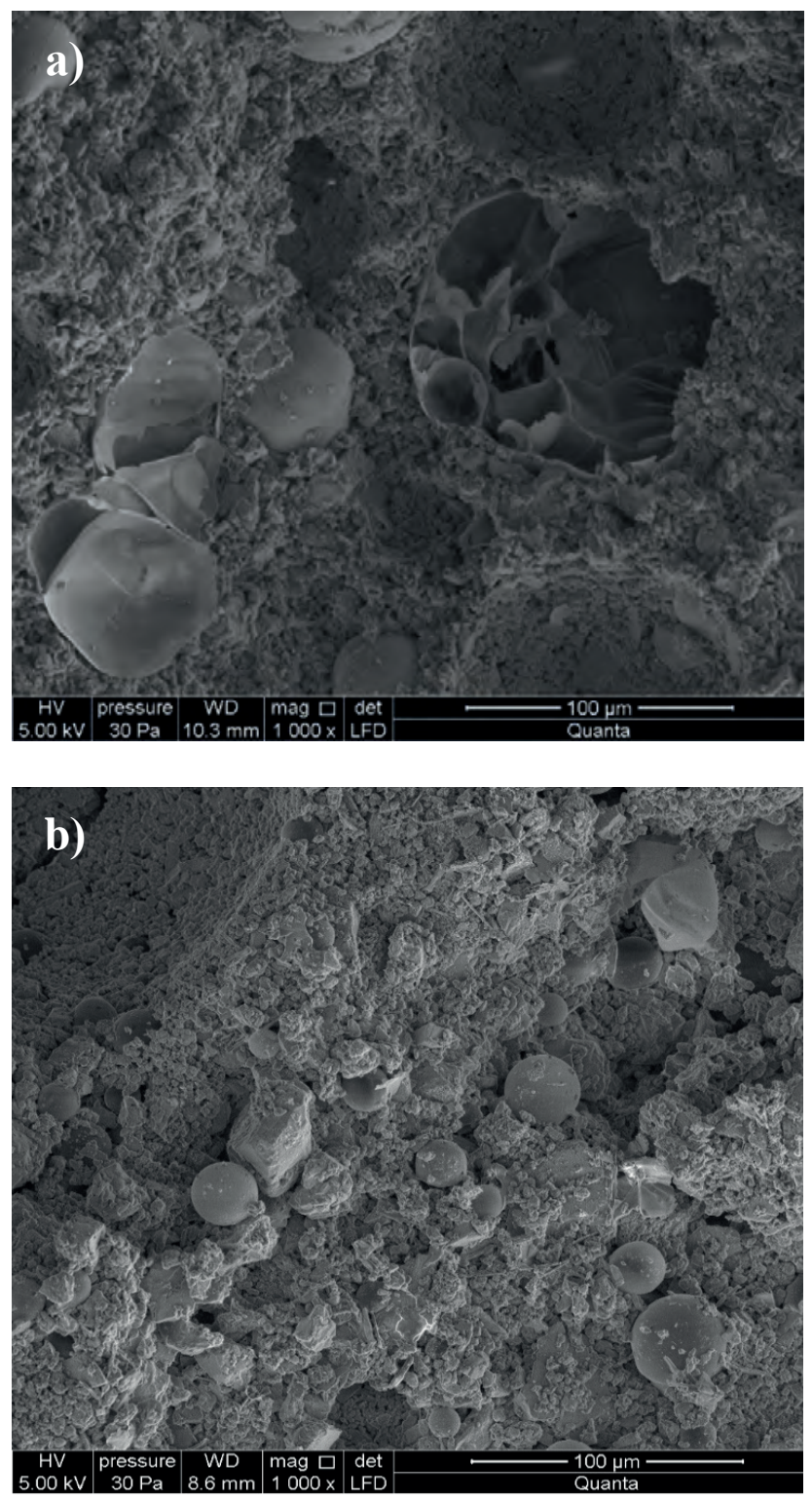

Fig. 2. Microstructure of chosen samples after 28 days of hydration: a) Z2 - cracked perlite grains well incorporated into cement matrix; b) Z5 - bad incorporation of polymer microspheres into mineral matrix

With the addition of perlite, the decrease of compressivestrength (-8.6\%) and an increase offlexural strength $(+7.7 \%)$ was observed, which is consistent with results presented in [14]. Thermal insulating properties and capillary absorption of mortar Z2 were not significantly changed when compared to control (Z1). Details are presented in Figure 4. Although slight decrease in thermal conductivity coefficient and also 
slight increase in capillary absorption were observed - which may suggest increase in porosity of sample, however, this effect can be equally attributed to the presence of lightweight filler as well as to increase of water/cement ratio - from 1.95 for control sample Z1 to 2.0 for $\mathrm{Z} 2$.

Scanning electron microscope observations were conducted after 28 days of hydration. As showed in Figure 2a, single particles of perlite are well incorporated into the cement matrix. Calcium Silicate Hydrates (C-S-H phase) built around the filler densely packed outer layer, with no interface border visible, created as a result of pozzolanic reaction $[15,16]$.

\subsection{Expanded glass}

The grain size distribution of expanded glass is comparable to silanized perlite but in a slightly narrower range of particle size - between $0.4 \mu \mathrm{m}$ to $125 \mu \mathrm{m}$. Singular grains have irregular shapes and characteristic microporosity as a result of the production process by foaming and milling. An addition of $5 \%$ (the highest of all tested materials) gave water demand a decrease of mortar Z3 from 39\% to $38 \%$. The reason is that lightweight filler, in this case, has coarser particles than dolomite flour which was replaced. It also proves low water absorption of expanded glass (in comparison with expanded perlite).

The compressive strength of mortar Z3 is over $30 \%$ higher than the control. At the same time, capillary absorption coefficient decrease - from $0.87 \mathrm{~kg} / \mathrm{m}^{2} \cdot \min ^{0.5}$ to $0.66 \mathrm{~kg} / \mathrm{m}^{2} \cdot \mathrm{min}^{0.5}$ and thermal conductivity coefficient increase - from $0.33 \mathrm{~W} / \mathrm{mK}$ to $0.36 \mathrm{~W} / \mathrm{mK}$ were observed. All obtained results indicate a decrease in porosity of hardened mortar comparing to the control sample, the most probably as a result of a pozzolanic reaction of expanded glass with calcium hydroxide formed during binder setting and hardening [17].

Some papers on alkali activation of milled waste from packaging glass can be found in the literature $[18,19]$. Such material shows high pozzolanic activity because of $100 \%$ of reactive glass phase content. Moreover, consumer glass can be characterized with a high content of alkaline oxides od sodium and potassium, acting as activators of reaction with portlandite - a product of cement hydration [20]. In this case also the reaction with hydrated lime added to the skim coat in the amount of $1 \%$ may occur.

The presented study shows that granulated expanded glass is lightweight filler with unique properties.
Despite decreasing the bulk density of final product $(6.7 \%$ - Table 1$)$, after 28 days of hydration, more densely packed microstructure was obtained - as the effect of pozzolanic reaction. The improvement of mechanical parameters occurred, and capillary absorption coefficient was decreased. However, thermal conductivity coefficient was increased which negatively impacts anti-condensation properties.

\subsection{Glass microspheres}

The addition of glass microspheres in the amount of $3 \%$ caused a slight increase in water demand of skim coat (from $39.5 \%$ to $40 \%$ ), an increase in flexural strength of $7.7 \%$ and a decrease of compressive strength of $9.9 \%$. Obtained results are almost identical as in case of silanized perlite. Considering chemical composition, also in this case, the pozzolanic reaction of filler and cement matrix can be expected, which results in an increase of flexural strength.

The main difference between these two lightweight fillers is particle size. Glass microspheres have significantly lower grains, in the range of $0-60 \mu \mathrm{m}$ with two clearly visible maximal values at $10 \mu \mathrm{m}$ and $30 \mu \mathrm{m}$ (Fig. 1). Further differences can be observed with a scanning electron microscope - contrary to perlite, singular microspheres have very regular shapes and show no visible porosity. This may result in lower water absorption, which could explain a lack of differences in water demand of the final formula with the same addition of perlite and glass microspheres, despite much finer grains of glass microspheres.

Air bubbles entrained to the mortar inside the hollow glass microspheres allowed for decreasing the thermal conductivity coefficient of mortar Z4 of as much as $15 \%$ when compared with the control sample, and almost $10 \%$ in comparison to the mortar with perlite. At the same time, the mortar was aerated with the air kept inside glassy shells, which prevented an increase of capillary porosity and a decrease of capillary absorption coefficient was observed - in comparison to control mortar. This is the only case from all tested lightweight fillers which by addition improved both: thermal insulation properties and resistance water uptake driven by capillary forces.

\subsection{Polymer microspheres}

Polymer microspheres were of the finest grain size from all fillers tested. They also have the highest impact on the consistency of the skim coat. With the addition of only $0.5 \%$, the increase in water demand from $38 \%$ to $43 \%$ was observed. For the sample Z5 
containing this filler, there was also found the highest mechanical strength decrease (of about $30 \%$ ). Finally, the highest capillary absorption was observed (Fig. 3). This is the result of higher water to cement ratio -2.15 in comparison to 1.9 for control. Moreover, because of chemical composition (thermoplastic copolymer), there is no pozzolanic activity of the filler. Therefore, no reaction with the cement matrix occurs and there is no possibility to compensate for increased porosity of hardened mortar, as it was in the case of other tested fillers.
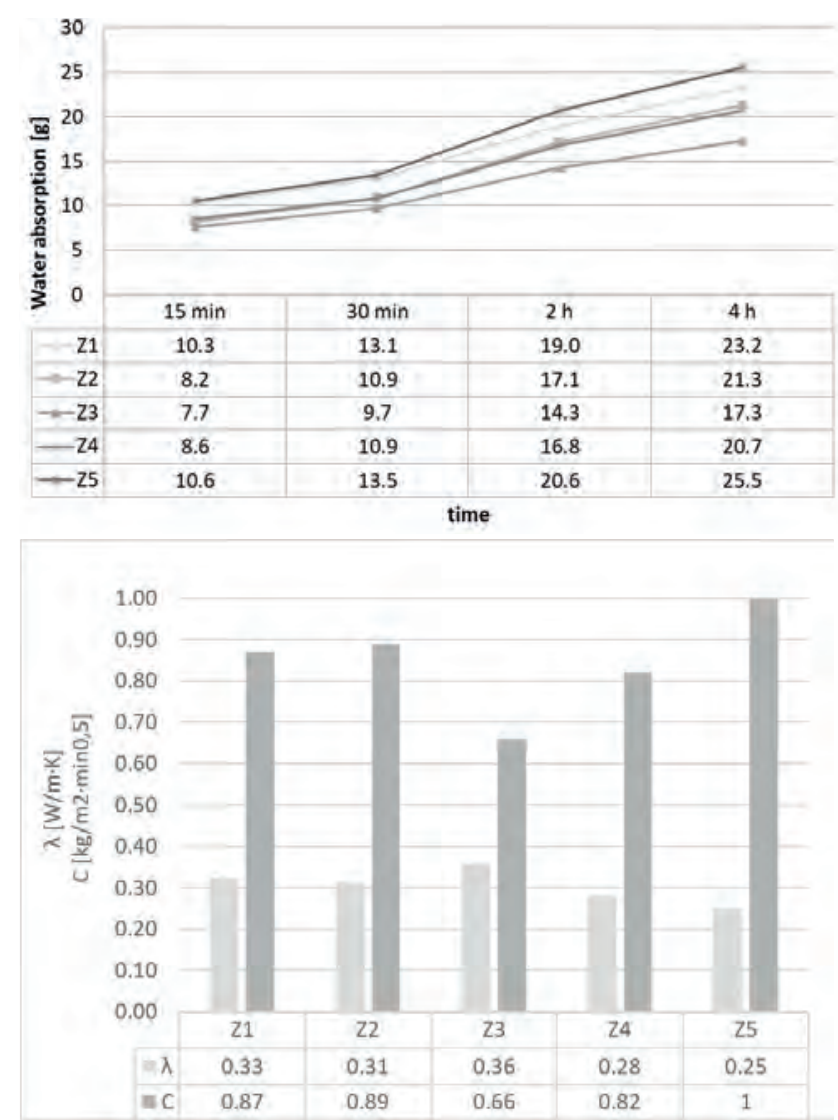

Fig. 3. Water uptake over time and capilary absorption coefficient $(C)$ vs Thermal conductivity coefficient $(\lambda)$

Microstructure observations by SEM confirm the poor incorporation of this filler into the mineral matrix. Singular microspheres are not tightly surrounded with the C-S-H phase and the contact zone is not as tightly packed as in the case of glass microspheres. With magnification of $1000 x$, the border between the matrix and the filler can be easily observed (Fig. 2b).

The addition of polymer microspheres gave a significant improvement in thermal insulative properties.A23\% decrease in the thermal conductivity coefficient was observed. This indicates such filler can be used as a component to formulate mortars with anti-condensation properties. Unfortunately, because of chemical incompatibility with the cement matrix, a significant decrease of other parameters was found. Better effect can be achieved by adding polymer microspheres to products based on organic binders [21].

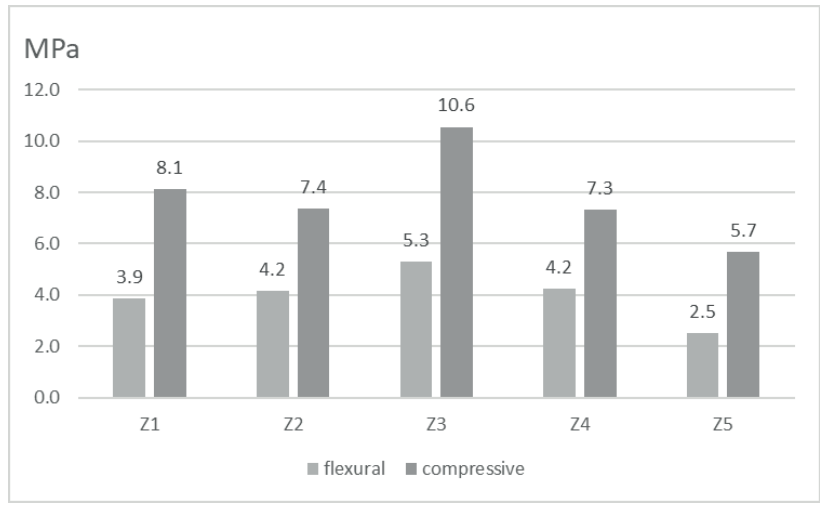

Fig. 4. Mechanical strength of the samples

\section{CONCLUSIONS}

In the present study, the impact of 4 different types of lightweight fillers on the performance of the cement-based skim coat was determined. The economical aspect was considered. The strong link between microstructure together with the composition of additive and mechanical strength was shown. Final products of different profiles were obtained.

The addition of expanded perlite and glass microspheres in the amount of 3\% gives a similar effect. In both cases, flexural strength is increased. Glass microspheres have a more favorable impact on thermal insulative properties and allow for the reduction of capillary absorption. Factor influencing negatively on final properties of mortars containing perlite is its open porosity resulting in relatively high water absorptivity - despite the silanization.

Granulated expanded glass is very attractive filler from the point of view of construction mortars producer. Addition of 5\% allowed for decreasing of bulk density of mortar with no increase of water demand. Better application properties and increased coverage capacity can be expected. At the same time, after 28 days of hydration (as the result of pozzolanic reaction), mechanical strength and resistance to capillary water absorption was improved. It is common that addition of lightweight fillers causes reduction of mechanical parameters. Disadvantages of granulated expanded glass is: relatively high bulk density (in relation to other lightweight fillers used in this study) and increase of thermal conductivity of final product. 
This is not the material suitable to formulate anticondensation coatings based on Portland cement.

The lowest thermal conductivity coefficient and bulk density was achieved by the addition of polymeric microspheres. However, because of the increase of water demand and poor incorporation of filler into the cement matrix, a significant decrease in mechanical parameters of the skim coat was observed. Nevertheless, the big potential of this filler as an additive supporting anti-condensation properties was observed - but further optimization of formula is necessary in order to improve mechanical parameters.

\section{REFERENCES}

[1] Yu B.F., Hu Z.B., Liu M., Yang H.L., Kong Q.X., Liu Y.H.: Review of research on air-conditioning systems and indoor air quality control for human health, International Journal of Refrigeration, 32 (2009), pp. 3-20.

[2] Ruckebusch J.M.: The use of $3 M^{\mathrm{TM}}$ Glass Bubbles to increase time until condensation forms on painted surfaces; Supplier technical report (2011).

[3] Rashad A.M.: A synopsis about perlite as building material - a best practice guide for civil engineer. Constr. Build. Mat. 121 (2016), pp. 338-353,

[4] Wang G., Chen D., Lu L. et al.: A novel anti-condensation coating. Journal of Coatings Technology (1998) 70: 55.

[5] Lanzón M., Garcia-Ruiz P.A.: Lightweight cement mortars: Advantages and inconveniences of expanded perlite and its influence on fresh and hardened state and durability. Construction and Building Materials 22 (2008), pp. 1798-1780.

[6] EN 13055-1:2002, Lightweight aggregates - Part 1: Lightweight aggregates for concrete, mortar and grout.

[7] Li Z. (2011): Advanced concrete technology, New York, NY:Wiley.

[8] Demirboga R., Orung I., Gul R.: Effects of expanded perlite aggregate and mineral admixtures on the compressive strength of low-density concretes. Cement and Concrete Research, 31(11), pp. 1627-1632. doi: 10.1016/S00088846(01)00615-9.

[9] Kramar D., Bindiganavile V.: Mechanical properties and size effects in lightweight mortars containing expanded perlite aggregate. Materials and Structures, 44(4), pp. 735-748, doi:10.1617/s11527-010-9662-0.

[10] Asad H., Zeyu L., Yu Ch., Su D., Zongjin L.: Effects of Different Lightweight Functional Fillers for Use in Cementitious Composites. International Journal of Concrete Structures and Materials, Vol. 11, No. 1, March 2017.

[11] Gardfors T.: Synthesis and Evaluation of Expancel ${ }^{\circledR}$ Microspheres. Degree Project in Engineering Chemistry, Umeå University (2013).

[12] May Yan Lee et al.: A Comparative Study of Production of Glass Microspheres by using Thermal Process, IOP Conf. Ser.: Mater. Sci. Eng. 205 (2017) 012022.

[13] Brooks A.L.: Comparative study of the mechanical and thermal properties of lightweight cementitious composites et al.: Construction and Building Materials 159 (2018), pp. 316-328.

[14] Nocuń-Wczelik W., Nowak M., Trybalska B.: Transport wody w zaprawach z dodatkiem perlitu ekspandowanego modyfikowanych domieszkami (Transport of water in the mortars with perlite addition modified by admixtures). PTcer (Ceramic Materials), IX Konferencja i Zjazd Polskiego Towarzystwa Ceramicznego, Zakopane, 19-22 IX 2013.

[15] Nocuń-Wczelik W., Nowak M., Kapeluszna E.: Lightweight Mortars with expanded perlite modified by admixtures. Structures \& Environment 31/2 (2017), pp. 102-111.

[16] Kotwica Ł., Pichór W., Nocuń-Wczelik W.: Study of pozzolanic action of ground waste expanded perlite by means of thermal methods. Jour. Therm. Anal. Calor. 123/1 (2016), pp. 607-613, doi: 10.1007/s10973-015-4910-8.

[17] Lanzón Torres M., García-Ruiz P.A.: Lightweight pozzolanic materials used in mortars: Evaluation of their influence on density, mechanical strength and water absorption. Cem. \& Concr. Comp. 31 (2009), pp. 114-119,

[18] Deja J., Gołek Ł., Kołodziej Ł.: Application of glass cullet in binder production. Cement, Wapno, Beton 16/6 (2011), pp. 349-354.

[19] Shao Y., Lefort T., Moras S., Rodriguez D.: 2000 Studies on concrete containing ground waste glass. Cem. Conc. Res.; 30(1), pp. 91-100; 2000.

[20] Gołek Ł.: Wpływ skladu chemicznego szkiet glinokrzemianowych na proces ich alkalicznej aktywacji - praca doktorska, AGH University of Science and Technology (2007).

[21] Wypych G.: Handbook of fillers, ChemTec Publishing (2016).

\section{Acknowledgments:}

The work was financed by Henkel Polska Ceresit International Center for Innovative Construction Technologies ul. Pitsudskiego 132B, 26-220 Staporków / Politechnika Świętokrzyska Kielce, al. Tysiaclecia Państwa Polskiego 7, 25-314 Kielce

\section{Podziękowania:}

Praca była finansowana przez Henkel Polska

Międzynarodowe Centrum Innowacyjnych Technologii Budowlanych Ceresit ul. Pitsudskiego 132B, 26-220 Staporków/ Politechnika Świętokrzyska Kielce, al. Tysiąclecia Państwa Polskiego 7, 25-314 Kielce 